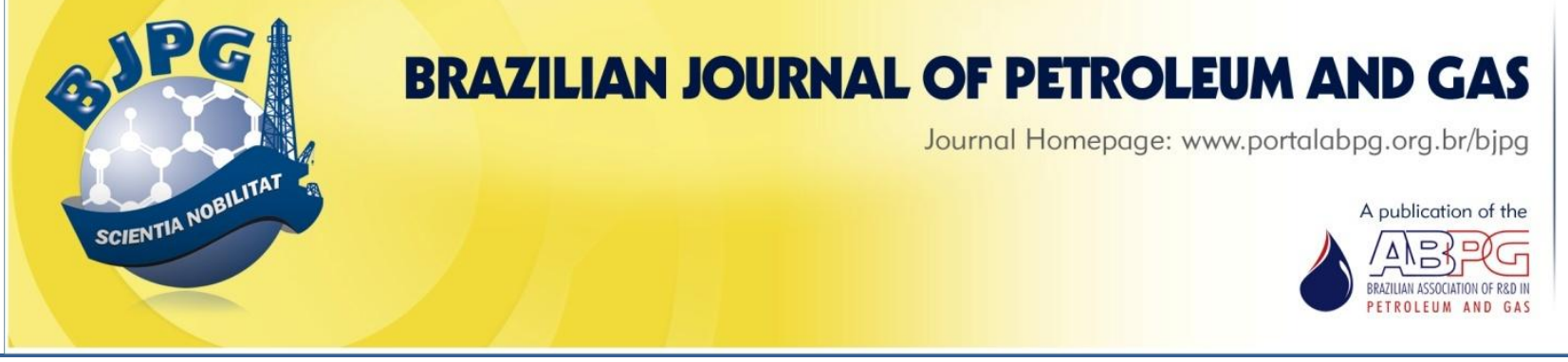

\title{
VALIDATION METHODOLOGY FOR IDENTIFICATION AND MEASUREMENT OF PHENOLIC COMPOUNDS IN OIL REFINERY EFFLUENT BY HPLC
}

\author{
${ }^{\text {a }}$ Zaidan, L. E. M. C. ${ }^{1}$; ${ }^{a}$ Napoleão, D. C.; ${ }^{a}$ Guimarães, G.; ${ }^{a}$ Barbosa, C. M. B. M.;

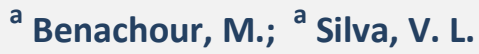 \\ ${ }^{a}$ Department of Chemical Engineering, Federal University of Pernambuco, Recife, Brazil
}

\begin{abstract}
The present work established a method, using High Performance Liquid Chromatography (HPLC) analysis, for the identification and quantification of five phenolic compounds. Chromatographic separation was performed by a reversed phase $\mathrm{C} 18$ column with a mobile phase consisting of methanol and aqueous $0.1 \%$ phosphoric acid in a ratio (10:90). The calibration curves showed excellent coefficients of determination $\left(R^{2} \geq 0.99\right)$ within the concentrations tested. The recoveries were $84.09 \%$ to $99.98 \%$ for spiked samples. The method can be adapted for the detection of phenolic compounds, which can be applied to monitor the effluent discharged into the environment.
\end{abstract}

\section{KEYWORDS}

HPLC; validation; phenolic compounds; oil refinery

\footnotetext{
${ }^{1}$ To whom all correspondence should be addressed.

Address: Department of Chemical Engineering, Federal University of Pernambuco, Av Prof. Moraes Rego, 1235 - University City - Recife - Brazil, Zip code: 50670-901.

Telephone / Fax: +55 81 2126-8711/ +55 81 2126-7290| E-mail: leaq val@yahoo.com.br; leazaidan@yahoo.com.br doi:10.5419/bjpg2013-0008
} 


\section{INTRODUCTION}

The effluents of an oil refinery are wastes that originated from industries are involved in the refining of crude oil, manufacturing fuels, lubricants and petrochemical byproducts. These effluents consist of oil and grease, together with other highly toxic organic compounds (Abdelwahab et al., 2009).

Effluents are formed by industrial organic and inorganic components created from raw materials, especially hydrocarbons. These contaminants, in nature, lead to severe environmental impacts due to their high oxygen demand and toxicity of the individual components in wastewater. Thus, restrictive regulations indicate the minimum levels allowed for disposal (Rizzo et al., 2006; Diya'udden et al., 2012).

The importance of detecting the presence of toxic substances and assess their impact on the environment is recognized globally. These actions lead to the development of a series of methodologies targeting environmental protection. The occurrence of phenolic compounds in wastewater has become a matter of international concern because of its adverse effects on human health and its dangerousness, persistence, and bioaccumulation in animals and plants (Awomeso et al., 2010; Osibanjo et al., 2011; Achi and ljeoma, 2011; Wang et al., 2012).

The presence of different concentrations of phenolic compounds has been detected in surface waters, causing a major concern facing the population. Studies have found toxicity in aquatic organisms, being detected in fish and plants. Moreover, polluted water bodies also serve as a source of drinking water for cities (Michalowicz et al., 2008). Several procedures for identification and quantification of phenolic compounds are reported in the literature. Among these techniques, the high performance liquid chromatography (HPLC) stands out (Tiburtius, 2008; Vrsaljko et al., 2012).

HPLC is a separation technique that, in less than thirty years, has become one of the most widely used analytical methods for qualitative and quantitative determinations. The reasons for this growth are related to its adaptability to quantitative analysis with suitable sensitivity. Using HPLC, one is able to perform the separation of nonvolatile and thermally unstable analytes, especially for applications in environmental samples (Collins, 2009). In analytical chemistry, to generate unambiguous data, free of error and uncertainty, is a difficult task. However, knowing the performance characteristics of a particular method, it becomes possible to ensure that the analytical measurements carried out by this method are close to the true unknown value, using the validation of analytical methods (Gozález and Herrador, 2007; Moraci, 2008).

Validation involves procedures that demonstrate the reliability of the method. The results validated provide credibility, precision, and accuracy. Although there is no agreement on which parameters should be included in a validation process, one should consider the following parameters (Lanças, 2009; Rambla-Alegre et al., 2012): linearity, accuracy, repeatability, selectivity, limit of quantification (LOQ), and limit of detection (LOD). Linearity indicates the ability to provide results directly proportional to the concentration of analyte in the sample in a given concentration range (Lanças, 2009; Cassiano et al., 2009).

The correlation between the analytical signal and the concentration of the substance represented by the equation of the regression line is called a calibration curve (Oliveira et al., 2005; Lanças, 2009; Cassiano et al., 2009; INMETRO, 2010; Souza, 2011; Rambla-Alegre et al., 2012).

The equation of the line obtained by the least squares method can be used to estimate the coefficients of the analytical curve and can be described as equation 1 .

$\mathrm{Y}=\mathrm{ax}+\mathrm{b}$

Where: $Y=$ dependent variable, measured response; $x=$ independent variable, concentration of analyte; $a=$ angular coefficient, expresses the slope of the graph to the axes; and $b=$ linear coefficient, expresses the intersection with the axes of the graph.

The correlation coefficient indicates the percentage of variance explained. Thus, the closer to 1 a correlation is $\left(R^{2}\right)$, the better the fit of the model will be (Otomo, 2010). The regulatory agency recommends a minimum of five concentration levels with a coefficient above 0.90 (INMETRO, 2003). Precision is a parameter evaluated based on the absolute standard 
deviation (SD), which uses a significant number of measurements, typically greater than 20. Another expression of precision is given by estimating the relative standard deviation $(R S D)$, also known as the coefficient of variation (CV), represented by equation 2:

$R S D(\%)$ or $C V(\%)=\frac{s}{x} \times 100$

Where: $s=$ estimate of the standard deviation; $\bar{x}=$ average.

Typically, methods for quantifying compounds in large amounts require a macro RSD of 1 to $2 \%$. For trace impurities, analytical methods $R S D$ up to $20 \%$ are accepted, depending on the complexity of the sample (Huber, 1998).

The precision in validation methods is considered at three different levels: repeatability, intermediate precision, and reproducibility (Oliveira, 2008). Repeatability expresses fidelity obtained under the same operating conditions (same analyst, same equipment, same method) applied in a short time interval (Lanças, 2009). According to the regulatory agency at least seven measurements should be carried out (INMETRO, 2003) in an experiment. The accuracy expresses the agreement between the value found and the value accepted as true, by reference (literature value), by comparison of methods tests, or by standard addition recovery (Oliveira, 2008; Lanças, 2009; Souza, 2011).

The standard addition method is applicable when it is not possible to obtain a sample free of the substance of interest. Based on the method of recovery, which is a ratio of the amount of substance of interest present and added to the sample, it is possible to extract and quantify the analyte (Souza, 2011). In practice, the study of recovery is accomplished by adding known concentrations of the analyte in the sample (Thompson et al., 2002; Ribani et al., 2004). Three levels of concentrations should be chosen for tests of recovery, and they should cover the range of use of the method. For more complex samples, the acceptable recovery ranges from $50 \%$ to $120 \%$ (Lanças, 2009; Perlatti et al., 2012). The calculation of recovery $(R)$ is performed according to equation 3.
$R(\%)=\left(\frac{C_{1}-C_{2}}{C_{3}}\right) \times 100$

Where: $C_{1}=$ concentration determined in the sample with addition of the standard; $C_{2}=$ concentration determined in the sample without addition of the standard; and $\mathrm{C}_{3}=$ concentration of added standard.

The limit of detection ( $L O D)$ is the smallest amount of an analyte which can be detected. However, it is not necessary to quantify an exact value (Lanças, 2009). The presence of analyte can be calculated in several ways: using the visual method. $L O D$ is estimated by multiplying 3 times standard deviation of the response $(3 * s)$, divided by the slope or gradient (Ribani et al., 2004; Souza, 2011; Napoleão, 2011).

The Limit of Detection ( $L O D)$ can be determined by the method based on the analytical curve parameters, using equation 4 (Thompson et al., 2002; Paschoal et al., 2008; Ribani et al., 2004; Napoleão, 2011; Tahmouzi et al., 2011; Perlatti et al., 2012).

$$
L O D=3.3 \times \frac{S}{S}
$$

Where: $s=$ estimate of the standard deviation and $S=$ slope of the analytical curve.

The limit of quantitation ( $L O Q$ ) is the smallest amount of an analyte which can be measured with enough accuracy and precision (Lanças, 2009). The limit of quantification ( $L O Q$ ) can be determined by the relationship between the estimated standard deviation of the response curve and the slope of the analytical curve, as shown in equation 5 (Oliveira, 2008; Ribani et al., 2009; INMETRO, 2010):

$L O Q=10 \times \frac{s}{S}$

This study focuses on validating analytical methodology for identification and quantification of phenolic compounds, with mutagenic and carcinogenic action, from industrial effluents. The validation process has provided objective evidence that the system and method are suitable for the intended use. 
Table 1. Specifications of products: phenol, hydroquinone, catechol, resorcinol and p-benzoquinone).

\begin{tabular}{ccccc}
\hline Organic Compound & manufacturer & Lot & Expiration date & Purity \\
\hline Phenol & Chem Service & $463-49 \mathrm{~A}$ & $03 / 17$ & $99.5 \pm 0.5 \%$ \\
Catechol & Chem Service & $468-126 \mathrm{~A}$ & $06 / 15$ & $99.5 \pm 0.5 \%$ \\
Hydroquinone & Chem Service & $456-90 \mathrm{~B}$ & $12 / 14$ & $99.5 \pm 0.5 \%$ \\
Resorcinol & Chem Service & $407-123 \mathrm{~B}$ & $09 / 17$ & $99.5 \pm 0.5 \%$ \\
p-benzoquinone & Chem Service & $463-151 \mathrm{~B}$ & $04 / 13$ & $99.5 \pm 0.5 \%$ \\
\hline
\end{tabular}

\section{MATERIALS AND METHODS}

\subsection{Preparation of standard solutions}

All the standards (phenol, hydroquinone, catechol, resorcinol, and p-benzoquinone) were weighed separately in analytical balance, accurate to 4 decimal places, and had values equivalent to $2000 \mathrm{mg}$. Table 1 shows the description of the standards of each organic compound (date of manufacture, batch, manufacturer and purity). The aliquots were diluted in deionized water in a volumetric flask to $1000 \mathrm{~mL}$ measured in order to obtain a concentration of the stock solution of each organic compound $2000 \mathrm{mg}^{-1} \mathrm{~L}^{-1}$.

From a standard solution (stock) prepared at 2000mg. $\mathrm{L}^{-1}, 15$ different dilutions were made $(2,4$, $6,8,10,20,30,50,70,80,100,120,140,160$, and $200 \mathrm{mg}^{-\mathrm{L}^{-1}}$ ) for phenol, hydroquinone, catechol, resorcinol, and $p$-benzoquinone together. Then, immediately following the dilution, the samples were analyzed by High Performance Liquid Chromatography (HPLC) (Shimadzu - Prominence).

\subsection{Determination of phenol using HPLC}

The experiment used a HPLC C18 reversed phase column $(5 \mu \mathrm{m}, 4.6 \times 250 \mathrm{~mm})$ and an UV detection (SPD-20A), for wavelengths between 254 and $270 \mathrm{~nm}$ for the determination of phenol and aromatic intermediates. The mobile phase consisted of a water solution acidified with phosphoric acid and methanol at a ratio of (90:10) with a flow of $0.75 \mathrm{~mL} \mathrm{~min}^{-1}$ in isocratic mode.

\subsubsection{Validation procedure}

The validation procedure was performed as described in the introduction. The recovery was performed by adding known concentrations of the analyte in the sample. Various concentrations of standard $\left(6,10\right.$, and $\left.30 \mathrm{mg} \cdot \mathrm{L}^{-1}\right)$ were added to a stock solution of $2 \mathrm{mg} \cdot \mathrm{L}^{-1}$ of each compound for the linear range comprised between 2 and $50 \mathrm{mg} \cdot \mathrm{L}^{-1}$. Concentrations of 70,100 , and $140 \mathrm{mg}^{-\mathrm{L}^{-1}}$ were used for the linear range between 50 and $200 \mathrm{mg}^{-\mathrm{L}^{-}}$ ${ }^{1}$ with final concentrations in the respective ranges of linearity of the method. Concentrations used in this work for linear range, were based on literature in wastewater from oil refinery concentrations, ranging between 2 to $200 \mathrm{mg}^{\mathrm{L}} \mathrm{L}^{-1}$.

\section{RESULTS AND DISCUSSION}

\subsection{Validation of analytical parameters: analysis by HPLC}

Seven analytical curves for phenol and its key intermediates (hydroquinone, resorcinol, catechol and $p$-benzoquinone) were prepared with eight different concentrations each. To identify each compound analyzed in the matrix by HPLC, the retention time was measured. This study, found that phenol had a retention time of $24.5 \mathrm{~min}-$ hydroquinone; $7.5 \mathrm{~min}$ - catechol; $14.5 \mathrm{~min}$ - $\mathrm{p}$ benzoquinone; $12.0 \mathrm{~min}$; and resorcinol, $11.8 \mathrm{~min}$. The compounds phenol, hydroquinone, resorcinol, and catechol were detected at a wavelength of $270 \mathrm{~nm}$ and p-benzoquinone at $254 \mathrm{~nm}$. Figures 1 and 2 show the chromatograms obtained for the respective standards of phenol and aromatic intermediates. The peaks present in the chromatograms showed a similar behavior when compared with experiments performed by other authors (Zazo et al., 2005; Timbani, 2011). 


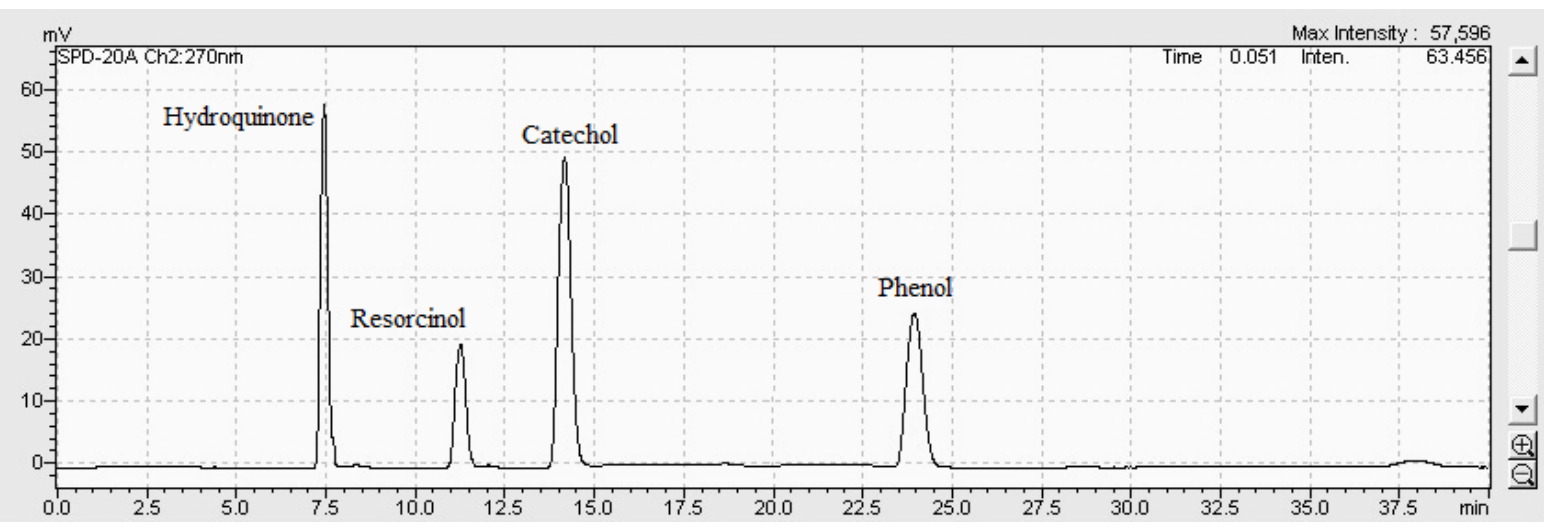

Figure 1. Chromatograms obtained for the standards of aromatic hydroquinone, resorcinol, catechol and phenol observed at a wavelength of $270 \mathrm{~nm}$.

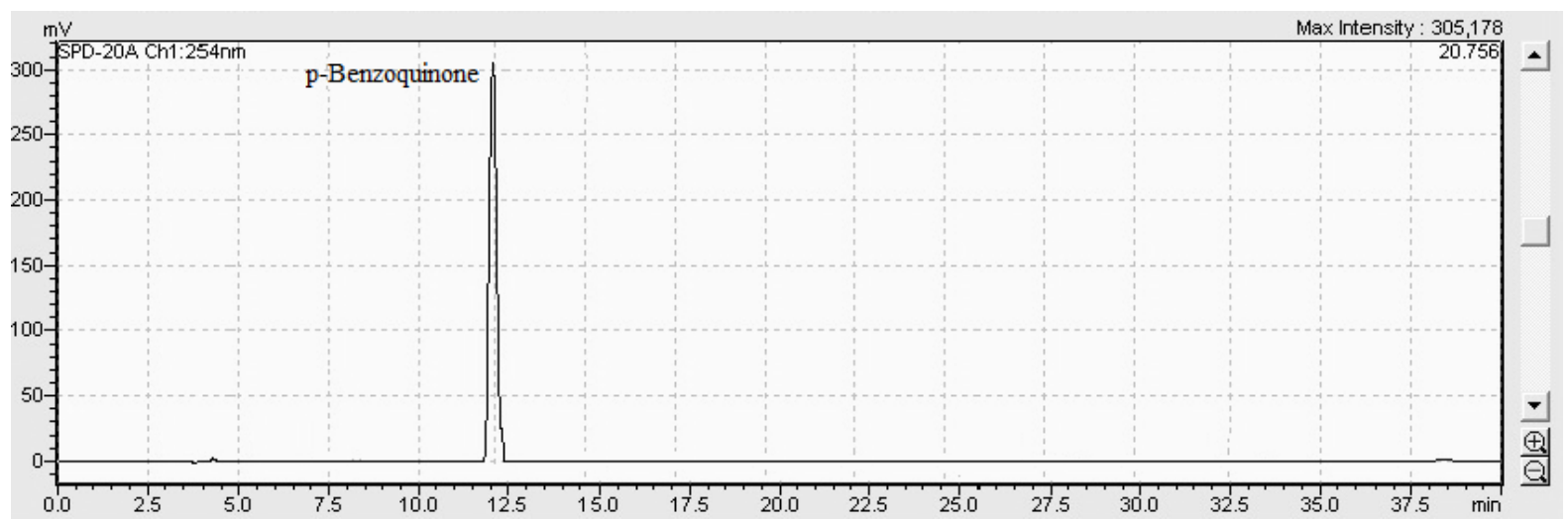

Figure 2. Chromatogram obtained for standard aromatic compound p-benzoquinone observed at a wavelength of $270 \mathrm{~nm}$.

From the obtained peak areas it was possible to calculate the mean and standard deviation between the areas. After obtaining these results, verified the existence of outliers by the method, through Grubbs' test. This test, note anomalous outliers appear larger or smaller than the group measures. Equations 6 and 7 are shown below:

$G_{<}=\frac{x-x_{i<}}{s}$

$G_{>}=\frac{x_{i>}-x}{s}$

Where: $G_{<}=$Grubbs' test to the lowest measured value; $G_{>}=$Grubbs' test for the greatest measured value; $\bar{x}=$ Average; $x_{i<}=$ minor extent; $x_{i>}=$ superior extent; $s=$ estimated standard deviation.
The mean area of each concentration of the compounds was carried out for 7 replicates, minimum required by regulatory agencies. Tables 2 and 3 show the results for the mean area, the standard deviation and Grubbs' test. The values obtained for the Grubbs' test had a value less than or equal to 2.020 , which confirmed a confidence level of $95 \%$ when considering the 7 replicates areas (Barros Neto et al., 2002).

\subsection{Analysis of linearity}

The linearity of the method was assessed by analytical curves of each compound, considering the correlation coefficient $\left(R^{2}\right)$ obtained by linear regression. Table 4 shows the linear ranges for each of the studied compounds, as well as equations of the lines and correlation coefficients obtained. 

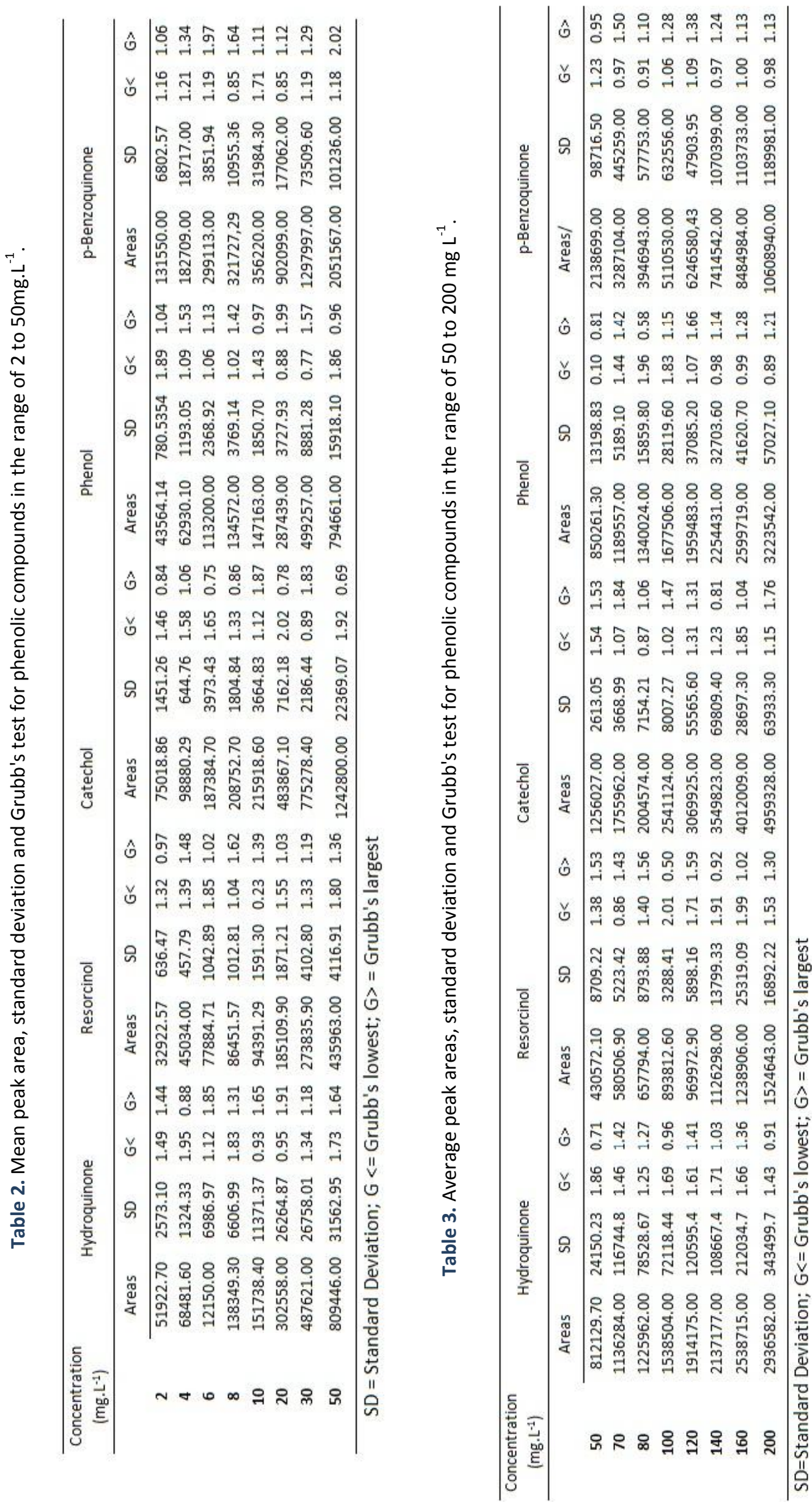
Table 4. Working range for each compound, straight-line equation, and determination coefficient $\left(R^{2}\right)$.

\begin{tabular}{cccc}
\hline Compound & Linear range $\left(\mathrm{mg} \cdot \mathrm{L}^{-1}\right)$ & Equation of the line & $\mathrm{R}^{2}$ \\
\hline Hydroquinone & 2 to 50 & $\mathrm{y}=15855 \mathrm{x}+8801.3$ & 0.9973 \\
\hline Resorcinol & 50 to 200 & $\mathrm{y}=14599 \mathrm{x}+10104$ & 0.9936 \\
\hline Catechol & 2 to 50 & $\mathrm{y}=8414.6 \mathrm{x}+17212$ & 0.9984 \\
\hline $\mathrm{p}$ & 2 to 200 & $\mathrm{y}=7262.1 \mathrm{x}+92673$ & 0.9916 \\
\hline $\mathrm{p}$-benzoquinone 50 & $\mathrm{y}=24716 \mathrm{x}+21550$ & 0.9967 \\
\hline & 50 to 200 & $\mathrm{y}=24912 \mathrm{x}+30473$ & 0.9994 \\
\hline Phenol & 2 to 50 & $\mathrm{y}=42379 x+14216$ & 0.9965 \\
\hline & 50 to 200 & $\mathrm{y}=56466 \mathrm{x}-579872$ & 0.9994 \\
\hline 2 to 50 & $\mathrm{y}=15822 \mathrm{x}+3240.3$ & 0.9958 \\
\hline & 50 to 200 & $\mathrm{y}=15698 \mathrm{x}+81536$ & 0.9996
\end{tabular}

Table 4 shows that the values of the respective compounds correlations were above 0.99 , being in accordance with the standards required by the regulatory agencies (ANVISA, 2003; INMETRO,
2010). The graphic representations of calibration curves for each of the compounds can be visualized in Figures 3 and 4.
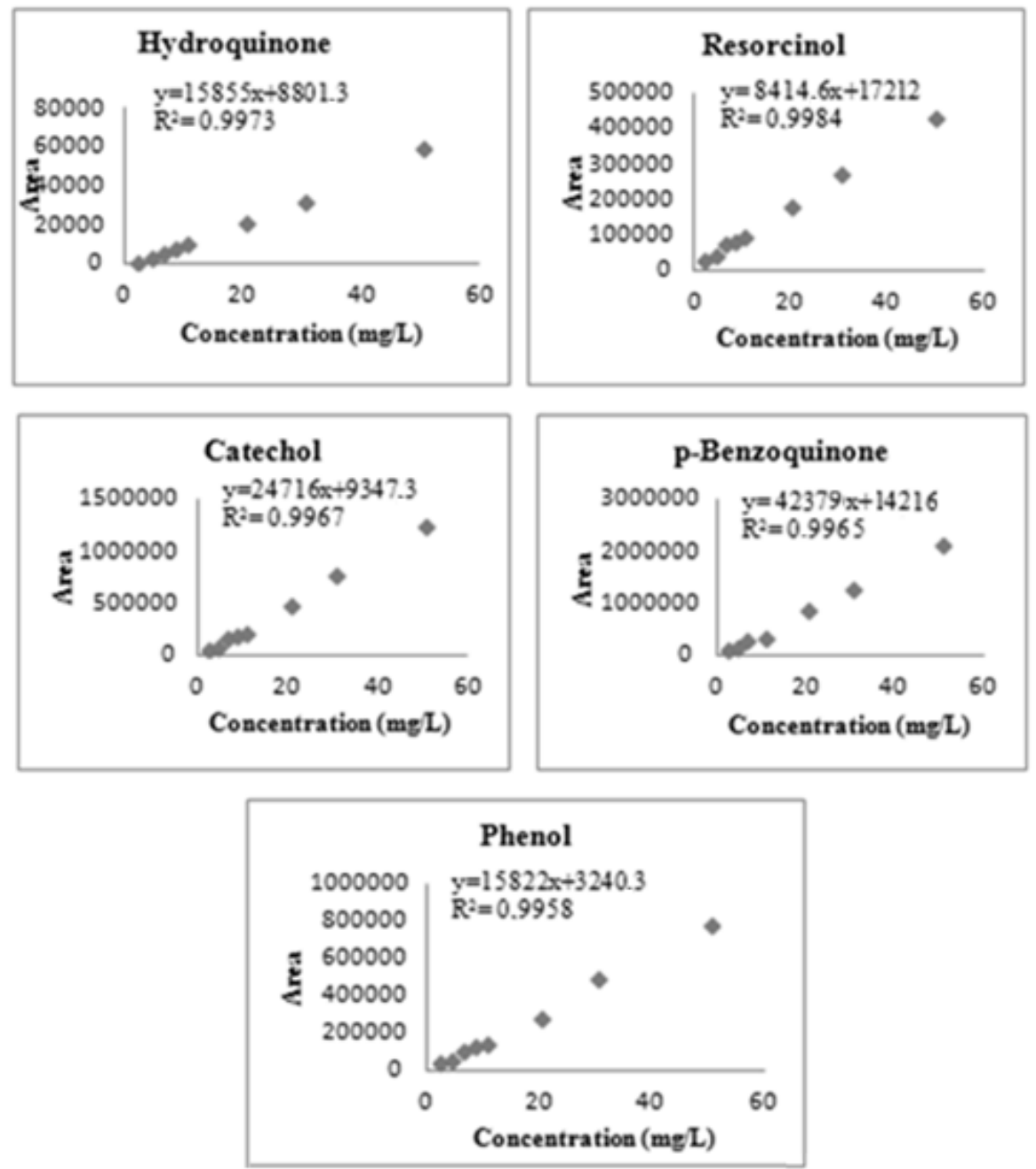

Figure 3. Graphical representation of linearity for the five compounds studied in the working range between $2-50 \mathrm{mg} \cdot \mathrm{L}^{-1}$. 

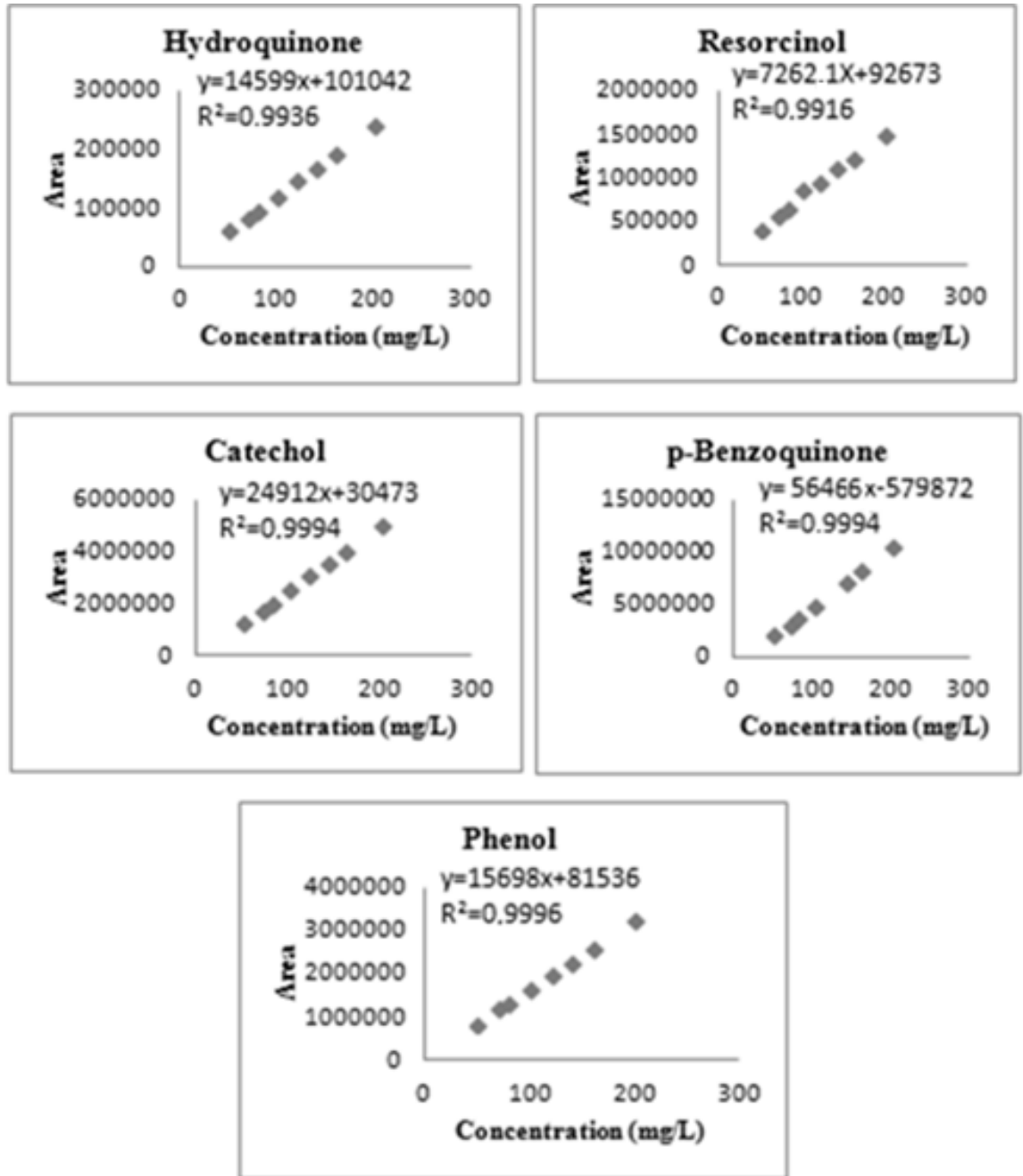

Figure 4. Graph of linearity for the five compounds investigated in the working range between 50-200 mg. $\mathrm{L}^{-1}$.

\subsection{Analysis of precision}

The analysis was performed with precision based on the measurement of coefficient of variation (CV). Calculations were performed according to equation 2. The $\mathrm{CV}$ values obtained for each concentration used in the construction of the curve are described in Tables 5 and 6 . The results for all compounds included in the work range between 2 to $50 \mathrm{mg} \cdot \mathrm{L}^{-1}$ and 50 to $200 \mathrm{mg} \cdot \mathrm{L}^{-1}$.

Table 5. Values obtained for the linear $\mathrm{CV}$ in the range $2-50 \mathrm{mg} \cdot \mathrm{L}^{-1}$.

\begin{tabular}{cccccc}
\hline & & \multicolumn{3}{c}{ Coefficient of Variance (CV) } & \\
\cline { 3 - 5 } $\begin{array}{c}\text { Concentration } \\
\left(\mathrm{mg.L}^{-1}\right)\end{array}$ & Hydroquinone & Resorcinol & Catechol & p-benzoquinone & Phenol \\
\hline 2 & 4.956 & 1.933 & 1.791 & 10.310 & 1.792 \\
4 & 1.934 & 1.017 & 0.604 & 10.240 & 1.896 \\
6 & 5.751 & 1.339 & 1.963 & 1.290 & 2.092 \\
8 & 4.776 & 1.172 & 0.800 & 3.41 & 2.801 \\
10 & 7.494 & 1.686 & 1.571 & 8.980 & 1.258 \\
20 & 8.648 & 1.011 & 1.714 & 19.630 & 1.297 \\
30 & 5.487 & 1.498 & 0.261 & 5.660 & 1.779 \\
50 & 3.899 & 0.944 & 1.719 & 13.660 & 2.003 \\
\hline
\end{tabular}


Table 6. Values obtained for the linear CV in the range 50-200 mg. $\mathrm{L}^{-1}$.

\begin{tabular}{cccccc}
\hline & & \multicolumn{3}{l}{ Coefficient of Variance (CV) } & \\
\cline { 3 - 5 } $\begin{array}{c}\text { Concentration } \\
\left(\text { mg. } \text { L }^{-1}\right)\end{array}$ & Hydroquinone & Resorcinol & Catechol & p-benzoquinon & Phenol \\
\hline 50 & 2.974 & 2.023 & 0.229 & 11.35 & 1.552 \\
70 & 10.274 & 0.900 & 0.230 & 13.96 & 0.436 \\
80 & 6.405 & 1.337 & 0.393 & 14.73 & 1.184 \\
100 & 4.688 & 0.368 & 0.315 & 12.30 & 1.676 \\
120 & 6.300 & 0.608 & 1.991 & 0.77 & 1.893 \\
140 & 5.085 & 1.225 & 2.163 & 14.53 & 1.451 \\
160 & 8.352 & 2.044 & 0.787 & 13.13 & 1.601 \\
200 & 11.697 & 1.108 & 1.418 & 11.34 & 1.769 \\
\hline
\end{tabular}

Table 7. - Limits of quantification of the analytical curve relating to organic compounds.

\begin{tabular}{cccccc}
\hline & & \multicolumn{2}{c}{ Limit of quantification (LOQ) } & \\
\cline { 3 - 5 }$\left(\mathrm{mg.L}^{-1}\right)$ & Phenol & Hydroquinone & Catechol & Resorcinol & p-benzoquinone \\
\hline $2-50$ & 0.493 & 1.623 & 0.587 & 0.760 & 2.354 \\
$50-200$ & 8.408 & 16.540 & 1.050 & 11.993 & 1.107 \\
\hline
\end{tabular}

Table 8. Detection limits of the analytical curve relating to organic compounds.

\begin{tabular}{cccccc}
\hline & & \multicolumn{2}{c}{ Limit of Detection $(L O D)$} & \\
\cline { 3 - 5 }$\left(\mathrm{mg}^{-1} \mathrm{~L}^{-1}\right)$ & Phenol & Hydroquinone & Catechol & Resorcinol & p-benzoquinone \\
\hline $2-50$ & 0.163 & 0.536 & 0.194 & 0.250 & 1.107 \\
$50-200$ & 2.775 & 5.460 & 0.350 & 3.958 & 14.456 \\
\hline
\end{tabular}

Table 9. Detection limits of the analytical curve relating to organic compounds.

\begin{tabular}{cccccc}
\hline $\begin{array}{c}\text { Concentration } \\
\left(\mathrm{mg.L}^{-1}\right)\end{array}$ & Phenol & Hydroquinone & Catechol & Resorcinol & p-benzoquinone \\
\hline $\begin{array}{c}2-6 \\
\text { (recovery) } \\
2-10\end{array}$ & $84.82 \%$ & $89.38 \%$ & $85.25 \%$ & $84.09 \%$ & $86.85 \%$ \\
$\begin{array}{c}\text { (recovery) } \\
2-30\end{array}$ & $98.26 \%$ & $88.20 \%$ & $99.44 \%$ & $90.35 \%$ & $94.84 \%$ \\
$\begin{array}{c}\text { (recovery) } \\
50-70\end{array}$ & $95.86 \%$ & $97.46 \%$ & $94.75 \%$ & $99.58 \%$ & $97.73 \%$ \\
$\begin{array}{c}\text { (recovery) } \\
50-100\end{array}$ & $94.09 \%$ & $92.51 \%$ & $98.98 \%$ & $92.51 \%$ & $97.73 \%$ \\
$\begin{array}{c}\text { (recovery) } \\
50-140\end{array}$ & $99.15 \%$ & $90.60 \%$ & $99.27 \%$ & $91.38 \%$ & $94.51 \%$ \\
\begin{tabular}{c} 
(recovery) \\
\hline
\end{tabular} & $98.41 \%$ & $99.89 \%$ & $98.83 \%$ & $99.32 \%$ & $91.90 \%$ \\
\hline
\end{tabular}

Based on these results, it was found that all determined coefficients of variance (CV) in the two linear ranges of each compound were acceptable for trace analysis or impurities (Ribani et al., 2004; Souza, 2011).

\subsection{Limit of Detection and Quantification}

Tables 7 and 8 show the results of $\angle O Q$ and $L O D$, respectively, for each of the organic compounds examined. 


\subsection{Analysis of accuracy}

The experiments were performed in triplicate. The calculations for recovery were obtained according to equation 2 . The results of the analysis (Table 9) show that, for all organic compounds studied, the average percentage of recoveries obtained were equal or higher than $84 \%$. These results demonstrate that the values were within the range recommended in the literature of 50 to $120 \%$ for complex samples (Lanças, 2009; Ribani et al., 2004; Souza, 2011).

\section{CONCLUSIONS}

The analytical methodology used a reverse phase HPLC that allowed a rapid detection and quantification of the phenolic compounds. The method comprised a mobile phase consisting of water acidified with phosphoric acid, methanol $\mathrm{pH}$ 2.2 (90:10), and UV detection at $270 \mathrm{~nm}$ for the compounds phenol, resorcinol, hydroquinone, and catechol, and $254 \mathrm{~nm}$ for p-benzoquinone. The technique was sensitive enough to identify and quantify all compounds proposed in this paper.

The proposed analytical method for the detection and quantification of five compounds were satisfactory in terms of linearity, precision, accuracy and stability in the range of interest.

The issues addressed in this work highlight the importance of validating the analytical methodology applied in chromatography. In the experimental part, the results show that all main parameters for validation of analytical methods required were within the range established by regulators.

\section{ACKNOWLEDGMENTS}

The authors wish to thank the LEAQ for supplying the active substances and acknowledge the financial support of PRH-28 ANP and FACEPE.

\section{REFERENCES}

Abdelwahab, N. K. Amin, E. S. Z. El-Ashtoukhy. Electrochemical removal of phenol from oil refinery wastewater. Journal Hazard Materials, v.163, p. 711-716, 2009. http://dx.doi.org/10.1016/i.jhazmat.2008.07.016

Achi, O. K.; Ijeoma, K. Industrial Effluents and Their Impact on Water Quality of Receiving Rivers in Nigeria. Journal of Applied Sciences in Environmental Sanitation, v.1, p.75-86, 2011.

Agência Nacional de Vigilância Sanitária (ANVISA); Resolução RE no899, de 29/05/2003. (In Portuguese)

Awomeso, J. A.; Taiwo, A. M.; Gbadebo, J. A. Adenowo. Studies on the Pollution of Waterbody by Textile Industry Effluents in Lagos, Nigeria. Journal of Applied Sciences in Environmental Sanitation, v.5, p.353-359, 2010.

Barros Neto, B.; Pimentel, M. F.; Araújo, M. C. U. Recomendações para calibração em Química Analítca - Parte 1. Fundamentos e calibração com um componente (Calibração Univariada), Química Nova, v. 25, p. $856-865,2002$. (In Portuguese) http://dx.doi.org/10.1590/\$0100-40422002000500024

Cassiano, N. M.; Barreiro, J. C.; Martins, I. R. R.; Oliveira, R. V.; Cass, Q. B. Validação em métodos cromatográficos para análises de pequenas moléculas em matrizes biológicas. Química Nova, v.32, p.1021-1030, 2009. (In Portuguese) http://dx.doi.org/10.1590/\$0100-40422009000400033

Collins, C. H. Os primórdios da cromatografia líquido-líquido. Scientia Chromatographica, v.1, n.3, 2009. (In Portuguese)

Diya'uddeen, B. H.; Daud, W. M. A. W.; Aziz, A. R. A. Treatment technologies for petroleum refinery effluents: A review. Process Safety and Environmental Protection, v.89, p. 95-105, 2012. http://dx.doi.org/10.1016/i.psep.2010.11.003

González, A. G.; Herrador, M. A. A practical guide to analytical method validation, including measurement uncertainly and accuracy profiles. Trend in Analytical Chemistry, v. 26, p.227-237, 2007. http://dx.doi.org/10.1016/j.trac.2007.01.009

Huber, L. Validation of analytical methods: review and strategy. LC-GC International, v.11, p. 96-105, 1998.

Instituto Nacional de Metrologia, Normalização e Qualidade Industrial (INMETRO), Orientações sobre Validação de Métodos de Ensaios Químicos Revisão: 01 de março de 2003, Brazil. (In Portuguese) 
Instituto Nacional de Metrologia, Normalização e Qualidade Industrial (INMETRO), Orientações sobre Validação de Métodos de Ensaios Químicos Revisão: 03 de Fevereiro de 2010, Brazil. (In Portuguese)

Lanças, F. M. A Cromatografia Líquida Moderna e a Espectrometria de Massas: finalmente "compatíveis"? Scientia chromatographica, v.1, n.2, 2009. (In Portuguese)

Michałowicz, J.; Bukowska, B.; Duda, W. Phenolic compounds in rivers exposed and nonexposed to anthropogenic pollution. Chemosphere, v.71, p. 735-741, 2008.

http://dx.doi.org/10.1016/j.chemosphere.2007.10.017

Moraci, L. F. S. Resíduos agrotóxicos em lodo de estação de tratamento de água para consumo humano: validação de metodologia analítica utilizando cromatografia líquida acoplada à espectrometria de massas em tandem (LCMS/MS). Dissertação de Mestrado. Programa de Pós-Graduação em Tecnologia Nuclear - Materiais, Universidade de São Paulo, 2008. (In Portuguese)

Napoleão, D. C. Avaliação e Tratamento dos Contaminantes Emergentes (Ácido Acetilsalicílico, Diclofenaco e Paracetamol) utilizando Processos Oxidativos Avançados. Dissertação de Mestrado. Programa de Pós-graduação em Engenharia Química - Universidade Federal de Pernambuco, 2011. (In Portuguese)

Oliveira, E. C. Comparação das diferentes técnicas para exclusão de "outliers". Congresso da Qualidade em Metrologia, São Paulo, Brazil, 2008. (In Portuguese)

Oliveira, A. M. C.; Lowen, T. C. R.; Cabral, L. M.; Santos, E. M.; Rodrigues, C. R. Helena, C. Castro, T. C. Santos. Development and validation of a HPLCUV method for the determination in didanosine tablets. Journal of Pharmaceutical and Biomedical Analysis, v.38, p. 751-756, 2005. (In Portuguese) http://dx.doi.org/10.1016/i.jpba.2005.02.004

Osibanjo, O.; Daso, A P.; Gbadebo A. M. The impact of industries on surface water quality of River Ona and River Alaro in Oluyole Industrial Estate, Ibadan, Nigeria. African Journal of Biotechnology, v.10, p. 696-702, 2011.
Otomo. J. I. Desenvolvimento e validação de metodologia analítica para determinação de hormônios, considerados disruptores endócrinos, nas águas destinadas ao abastecimento público na região do Rio Paraíba do Sul, SP. Dissertação de mestrado. Programa de Pós-Graduação em Tecnologia Nuclear - Materiais, Universidade de São Paulo, 2010. (In Portuguese)

Paschoal, J. A.; Rath, S.; Airoldi, F. P. S.; Reyes, F. G. R. Validação de métodos cromatográficos de determinação de resíduos de medicamentos veterinários em alimentos, Química Nova, v. 31, p. 1190-1198, 2008. (In Portuguese) http://dx.doi.org/10.1590/\$0100-40422008000500048

Perlatti, B.; Silva, M. F. G. F.; Fernandes, J. B.; Forim, M. R. Validation and application of HPLCESI-MS/MS method for the quantification of RBBR decolorization, a model for highly toxic molecules, using several fungi strains. Bioresource Technology, v.124, p.37-44, 2012.

http://dx.doi.org/10.1016/i.biortech.2012.08.032

Rambla-Alegre, M.; Esteve-Romero,J.; CardaBroch, S. Is it really necessary to validate an analytical method or not? That is the question. Journal of Chromatography A, v. 1232, p.101-109, 2012. http://dx.doi.org/10.1016/j.chroma.2011.10.050

Ribani, M.; Bottoli, C. B. G.; Collins, C. H.; Jardim, I. C. F. S.; Melo, L. F. C. V. Validação em métodos cromatográficos e eletroforéticos. Química Nova, v.27, p.771-780, 2004. (In Portuguese)

http://dx.doi.org/10.1590/\$0100-40422004000500017

Rizzo, A. C. L.; Leite, S. G. F.; Soriano, A. U.; Corrêa dos Santos, R. L.; Sobral, L. G. S. Biorremediação de solos contaminados por petróleos: ênfase no uso de biorreatores. Série Tecnologia ambiental, STA - 37. Versão Provisória. CETEM/MCT, 2006. (In Portuguese)

Souza, R. R. Desenvolvimento e validação de metodologia analítica para determinação de desregulação endócrina resultante de atividades antrópicas nas águas do Rio Paraíba do Sul. Dissertação de mestrado. São Paulo, 2011. (In Portuguese) 
Tahmouzi, S.; Khaksar, R.; Ghasemlou, M. Development and validation of an HPLC-FLD method for rapid determination of histamine in skipjack tuna fish (Katsuwonus pelamis). Food Chemistry, v.126, p. 756-761, 2011.

http://dx.doi.org/10.1016/i.foodchem.2010.11.060

Thompson, M.; Ellison, S. R. L.; Wood, R. Harmonized guidelines for single laboratory validation of method of analysis. IUPAC Technical Report. Pure Applied Chemistry, v.72, p.835-855, 2002. http://dx.doi.org/10.1351/pac200274050835

Tiburtius. E. R. L. Remediação de solo e águas subterrâneas contaminados com compostos orgânicos voláteis (BTX), utilizando processos Fenton e lavagens biosurfactantes. Tese de Doutorado. Programa de Pós-Graduação em Química Analítica, Universidade Federal do Paraná, 2008. (In Portuguese)

Timbani, P. C. Estudo da degradação de fenol e seus intermediários pelo processo $\mathrm{UV} / \mathrm{H}_{2} \mathrm{O}_{2}$. Dissertação de Mestrado. Programa de PósGraduação em Engenharia Química, Universidade de São Paulo, 2011. (In Portuguese)
Vrsaljko, D.; Haramija, V.; Hadži-Skerley, A. Determination of phenol, $m$-cresol and $o$-cresol in transformer oil by HPLCmethod. Electric Power Systems Research v.93, p. 24-31, 2012. http://dx.doi.org/10.1016/i.epsr.2012.07.006

Wang, D.; Zhong, W.; Xu, X. Phenol removal efficiencies of sewage treatment processes and ecological risks associated with phenols in effluents, Research Center for Eco-Environmental Sciences, Chinese Academy of Science, v.217-218, p. 286-292, 2012.

Zazo, J. A.; Casas, J. A.; Rodriguez, J. S. Chemical pathway and kinetics of phenol oxidation by Fenton's reagent. Environmental Science \& Technology, v.39, p. 9295-9302, 2005. http://dx.doi.org/10.1021/es050452h 